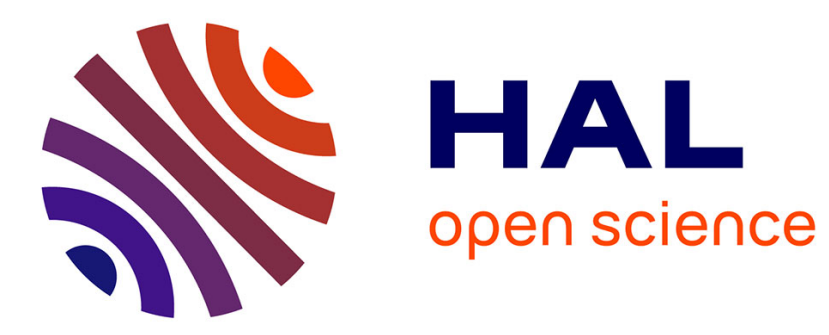

\title{
Combined and genotypes together with a stressful life event increase breast cancer risk
}

Christina Justenhoven, Stefan Winter, Thomas Dünnebier, Ute Hamann, Christian Baisch, Sylvia Rabstein, Anne Spickenheuer, Volker Harth, Beate Pesch, Thomas Brüning, et al.

\section{To cite this version:}

Christina Justenhoven, Stefan Winter, Thomas Dünnebier, Ute Hamann, Christian Baisch, et al.. Combined and genotypes together with a stressful life event increase breast cancer risk. Breast Cancer Research and Treatment, 2010, 124 (1), pp.289-292. 10.1007/s10549-010-1093-7 . hal-00563447

\section{HAL Id: hal-00563447 https://hal.science/hal-00563447}

Submitted on 5 Feb 2011

HAL is a multi-disciplinary open access archive for the deposit and dissemination of scientific research documents, whether they are published or not. The documents may come from teaching and research institutions in France or abroad, or from public or private research centers.
L'archive ouverte pluridisciplinaire HAL, est destinée au dépôt et à la diffusion de documents scientifiques de niveau recherche, publiés ou non, émanant des établissements d'enseignement et de recherche français ou étrangers, des laboratoires publics ou privés. 


\section{Letter to the Editor}

\section{Combined $U G T 1 A 1$ and $U G T 1 A 6$ genotypes together with a stressful life event increase}

\section{breast cancer risk}

Christina Justenhoven ${ }^{1}$, Stefan Winter ${ }^{1}$, Thomas Dünnebier ${ }^{2}$, Ute Hamann ${ }^{2}$, Christian Baisch ${ }^{3}$, Sylvia Rabstein ${ }^{4}$, Anne Spickenheuer ${ }^{4}$, Volker Harth ${ }^{4}$, Beate Pesch $^{4}$, Thomas Brüning ${ }^{4}$, YonDschun $\mathrm{Ko}^{3}$, Hiltrud Brauch ${ }^{1}$

${ }^{1}$ Dr. Margarete Fischer-Bosch-Institute of Clinical Pharmacology, Stuttgart, and University Tuebingen, Germany

${ }^{2}$ Molecular Genetics of Breast Cancer, Deutsches Krebsforschungszentrum (DKFZ), Heidelberg, Germany

${ }^{3}$ Department of Internal Medicine, Evangelische Kliniken Bonn gGmbH, Johanniter Krankenhaus, Bonn, Germany

${ }^{4}$ Institute for Prevention and Occupational Medicine of the German Social Accident Insurance (IPA), Bochum, Germany

Correspondence to Dr Christina Justenhoven, Dr Margarete Fischer-Bosch-Institute of Clinical Pharmacology, Auerbachstrasse 112, D-70376 Stuttgart, Germany

Tel: + 49711 81015765; fax + 49711 859295; e-mail: christina.justenhoven@ ikp-stuttgart.de Key words: UGT1 A1; UGT1 A6: polymorphisms; stressful life event; breast cancer risk To the Editor,

Breast cancer is a multifactor disease and causative factors include genetic variations i.e. mutations and polymorphisms as well as epidemiological risks. BRCA1 and BRCA2 germline 
mutations and other rare mutations at ATM, BRIP1, CHEK and PALB2 are causative for hereditary breast cancers [1-3], and among common variants the cell signaling and cell growth factor FGFR2 polymorphism rs2981582 is the most prominent genetic risk [1]. While the search for breast cancer susceptibility genes has been extended to whole genome approach and continues at fast pace, breast cancer risks remains a complex phenomenon contributed by a plethora of epidemiological factors (e.g. age, early age at menarche, family history of breast cancer) $[1,4,5]$, and stressful life events are considered as a contributor [6-8]. This is plausible because stress has been appreciated as a known risk for several physical disorders including migraines, asthma, high blood pressure and cardiovascular diseases [9-11]. Whether and how stress contributes to cancer, in particularly breast cancer, remains elusive [12-14]. Moreover, whether there is an interaction of stressful life events with genetic variations in breast cancer risk has not been explored. The most suitable incisive life event is the loss of a significant other (death of a husband or divorce) rather than other events such as loss of a job, change in residence or financial problems that have been shown to be subject to selective remembering in the time of breast cancer diagnosis [7, 15]. Following the strategy of testing the association between stressful life events and other factors such as genetic variation, we employed a population-based case control study as recommended by Levav et al. [16]. We investigated a potential impact of genetic polymorphisms located in the UDP glucuronosyl transferases $1 \mathrm{~A} 1$ and $1 \mathrm{~A} 6$ (UGT1A1 and UGT1A6) on breast cancer risk of women who reported divorce/separation or death of a husband.

UGTs are suggested to play a critical role in breast carcinogenesis because they are key enzymes of the metabolism of endogenous and exogenous compounds including steroid hormones, xenobiotics and drugs $[17,18]$. Several polymorphisms have been described in UGT genes and some genetic variations are known to affect expression and activity of the encoded enzymes [18-20]. In the present study we selected one promoter polymorphism in UGT1A1 (UGT1A1_(TA) TAA repeat, UGT1A1*28) and two non-synonymous 
polymorphisms in UGT1A6 (UGT1A6_19_T >G, UGT1A6*2, $\operatorname{Ser}^{7} \mathrm{Ala}, \quad$ rs6759892 and UGT1A6_541_A>G, UGT1A6*2, Thr ${ }^{181} \mathrm{Ala}, \mathrm{rs} 2070959$, UGT1A6*2). These polymorphism $^{*}$ are linked to each other and the variant alleles are suggested to lead to a decreased expression of UGT1A1 and UGT1A6 [21-23]. Moreover, a possible reduction of side effects detoxification, increase of unwanted side effects of drugs and susceptibility of some diseases such as hepatocellular or breast carcinoma have been discussed for the variant alleles [23-25]. Accordingly, there is a possibility that these genetic variants may be involved in the metabolic dysregulation of known and putative endogenous and exogenous breast carcinogens potentially provoked by stressful events.

We analyzed the UGT1A1*28 and UGT1A6*2 polymorphisms in 1021 breast cancer cases and 1015 controls of the GENICA collection, a German age-matched population-based case control study [26, 27]. The GENICA study was approved by the Ethic's Committee of the University of Bonn. All study participants gave written informed consent. The UGT1A1_(TA)n TAA repeat was genotyped using MegaBACE 1000 DNA Analyzer (GE Health Care Biosciences Corp. Piscata Way, NY, USA) and UGT1A6_19_T $>\mathrm{G}$ as well as UGT1A6_541_A>G were genotyped by matrix assisted laser desorption/ionization mass spectrometry (MALDI-TOF MS; Sequenom, San Diego, CA) as described previously [24]. In case of the UGT1A1_(TA)n TAA repeat carriers of $5 / 6$ or $6 / 6$ repeats were designated as homozygous $* 1$, carriers of $5 / 7,6 / 7$ or $6 / 8$ repeats were designated heterozygous $* 1 / * 28$ as well as carriers of $7 / 7$ or $7 / 8$ repeats were designated homozygous $* 28$. In case of UGT1A6 carriers of the UGT1A6_19_TT and UGT1A6_541_AA genotypes were designated homozygous *1 and carriers of the variant UGT1A6_19_GG and UGT1A6_541_GG genotypes were designates homozygous $* 2$. All women homozygous for $U G T 1 A l^{*} 1$ and $U G T 1 A 6^{*} 1(+)$ as well as all women homozygous for $U G T 1 A 1^{* 28}$ and $U G T 1 A 6^{*} 2(-)$ were included in the statistical analysis. The following subgroups were used in the association analysis: (i) women who reported to be unmated (never lived with a partner or husband), (ii) 
women which currently life with a partner or husband, and (iii) women that reported separation/divorce/death of husband. Associations between the combined UGTIAl and UGT1A6 genotypes and breast cancer risk were analyzed by logistic regression conditional on age (5-year groups) and adjusted for six epidemiological breast cancer risk factors (i.e. menopausal status, family history of breast cancer, use of oral contraceptives, use of hormone therapy, body mass index, and smoking). Statistical analyses were performed using SAS v9.1.3 (S AS Institute Inc., Cary, NC, USA).

At baseline, there was no risk association with stressful live events (Table 1). However, we observed a significantly increased breast cancer risk for women carrying the $U G T 1 A 1 * 28$ and $U G T 1 A 6^{*} 2$ variant genotype (-) as compared to women carrying the common $U G T 1 A 1^{*} 1$ and UGT1A6*1 genotype (+) with an odds ratio (OR) of 1.51 (95\% confidence interval [CI]: 1.10$2.09, \mathrm{p}=0.012$; Table 1).

When we performed a combined analysis for $U G T$ genotypes and life events we observed an elevated breast cancer risk with an OR of 2.61 (95\% CI: 1.29-5.29, $\mathrm{p}=0.008$; Table 1) for women carrying the $U G T$ variant genotype (-) and reporting separation/divorce/death of husband. Since UGTs are involved in the elimination of sex hormones from the circulation any lower activity, e.g. due to the background of $U G T 1 A 1 * 28$ and $U G T 1 A 6^{*} 2$ genotypes (-), expected to increase estrogen levels [21-23]. It is of note because elevated estrogen levels are known to be critical for carcinogenesis of breast tumors [28]. This effect can be promoted by stressful events that may further impact on the dysregulation of the metabolism of hormone related carcinogens. In the absence of a baseline risk of stress events, our results suggest, that a small breast cancer risk conveyed by UGTIAI and UGTIA6 variants may be further amplified by the experience of persisting stressful events. To challenge this hypothesis our findings should be followed up in larger patient cohorts.

\section{Acknowledgements}


We are indebted to all women participating in the GENICA study. We gratefully acknowledge support by interviewers as well as physicians and pathologists of the study region. Genotyping analyses were supported by Sandra Brod and Michael Gilbert. This work was supported by the Federal Ministry of Education and Research (BMBF) Germany grants 01KW9975/5, 01KW9976/8, 01KW9977/0, 01KW0114, and 012P0502, the Robert Bosch Foundation of Medical Research, Stuttgart, Deutsches Krebsforschungszentrum, Heidelberg, Institute for Prevention and Occupational Medicine of the German Social Accident Insurance (IPA), Bochum Department of Internal Medicine, Evangelische Kliniken Bonn gGmbH, Johanniter Krankenhaus, Bonn, Germany.

All authors disclose any actual or potential conflict of interest including any financial, personal or other relationships with other people or organizations.

\section{References}

1. Easton DF, Pooley KA, Dunning AM, Pharoah PD, Thompson D, Ballinger DG, Struewing JP, Morrison J, Field H, Luben R, Wareham N, Ahmed S, Healey CS, Bowman R, Meyer KB, Haiman CA, Kolonel LK, Henderson BE, Le ML, Brennan P, Sangrajrang S, Gaborieau V, Odefrey F, Shen CY, Wu PE, Wang HC, Eccles D, Evans DG, Peto J, Fletcher O, Johnson N, Seal S, Stratton MR, Rahman N, ChenevixTrench G, Bojesen SE, Nordestgaard BG, Axelsson CK, Garcia-Closas M, Brinton L, Chanock S, Lissowska J, Peplonska B, Nevanlinna H, Fagerholm R, Eerola H, Kang D, Yoo KY, Noh DY, Ahn SH, Hunter DJ, Hankinson SE, Cox DG, Hall P, Wedren S, Liu J, Low YL, Bogdanova N, Schurmann P, Dork T, Tollenaar RA, Jacobi CE, Devilee P, Klijn JG, Sigurdson AJ, Doody MM, Alexander BH, Zhang J, Cox A, Brock IW, MacPherson G, Reed MW, Couch FJ, Goode EL, Olson JE, Meijers- 
Heijboer H, van den OA, Uitterlinden A, Rivadeneira F, Milne RL, Ribas G, Gonzalez-Neira A, Benitez J, Hopper JL, McCredie M, Southey M, Giles GG, Schroen C, Justenhoven C, Brauch H, Hamann U, Ko YD, Spurdle AB, Beesley J, Chen X, Mannermaa A, Kosma VM, Kataja V, Hartikainen J, Day NE, Cox DR, Ponder BA (2007) Genome-wide association study identifies novel breast cancer susceptibility loci. Nature 447:1087-93.

2. Ford D, Easton DF, Stratton M, Narod S, Goldgar D, Devilee P, Bishop DT, Weber B, Lenoir G, Chang-Claude J, Sobol H, Teare MD, Struewing J, Arason A, Scherneck S, Peto J, Rebbeck TR, Tonin P, Neuhausen S, Barkardottir R, Eyfjord J, Lynch H, Ponder BA, Gayther SA, Zelada-Hedman M, et al. (1998) Genetic heterogeneity and penetrance analysis of the BRCA1 and BRCA2 genes in breast cancer families. The Breast Cancer Linkage Consortium. Am J Hum Genet 62:676-89.

3. Narod S, Ford D, Devilee P, Barkardottir RB, Eyfjord J, Lenoir G, Serova O, Easton D, Goldgar D (1995) Genetic heterogeneity of breast-ovarian cancer revisited. Breast Cancer Linkage Consortium. Am J Hum Genet 57:957-8.

4. Hulka BS, Moorman PG (2001) Breast cancer: hormones and other risk factors. Maturitas 38:103-13.

5. Kelsey JL, Gammon MD (1991) The epidemiology of breast cancer. CA Cancer J Clin 41:146-65.

6. Kruk J, boul-Enein HY (2004) Psychological stress and the risk of breast cancer: a case-control study. Cancer Detect Prev 28:399-408. 
7. Lillberg K, Verkasalo PK, Kaprio J, Teppo L, Helenius H, Koskenvuo M (2003) Stressful life events and risk of breast cancer in 10,808 women: a cohort study. Am J Epidemiol 157:415-23.

8. Steptoe A, Wardle J (1994) What the experts think: a European survey of expert opinion about the influence of lifestyle on health. Eur J Epidemiol 10:195-203.

9. Chorot P, Sandin B (1994) Life events and stress reactivity as predictors of cancer, coronary heart disease and anxiety disorders. Int J Psychosom 41 :34-40.

10. Ginsberg A, Price S, Ingram D, Nottage E (1996) Life events and the risk of breast cancer: a case-control study. Eur J Cancer 32A:2049-52.

11. Rahe RH, Bennett L, Romo M, Siltanen P, Arthur RJ (1973) Subjects' recent life changes and coronary heart disease in Finland. Am J Psychiatry 130:1222-6.

12. Cohen S, Rabin BS (1998) Psychologic stress, immunity, and cancer. J Natl Cancer Inst 90:3-4.

13. Garssen B, Goodkin K (1999) On the role of immunological factors as mediators between psychosocial factors and cancer progression. Ps ychiatry Res 85:51-61.

14. McGee R, Williams S, Elwood M (1996) Are life events related to the onset of breast cancer. Psychol Med 26:441-7.

15. Funch DP, Marshall JR (1984) Measuring life stress: factors affecting fall-off in the reporting of life events. J Health Soc Behav 25:453-64.

16. Levav I, Kohn R, Iscovich J, Abramson JH, Tsai WY, Vigdorovich D (2000) Cancer incidence and survival following bereavement. Am J Public Health 90:1601-7. 
17. Mackenzie PI, Owens IS, Burchell B, Bock KW, Bairoch A, Belanger A, FournelGigleux S, Green M, Hum DW, Iyanagi T, Lancet D, Louisot P, Magdalou J, Chowdhury JR, Ritter JK, Schachter H, Tephly TR, Tipton KF, Nebert DW (1997) The UDP glycosyltransferase gene superfamily: recommended nomenclature update based on evolutionary divergence. Pharmacogenetics 7:255-69.

18. Riedmaier S, Klein K, Hofmann U, Keskitalo JE, Neuvonen PJ, Schwab M, Niemi M, Zanger UM (2010) UDP-glucuronos yltransferase (UGT) polymorphisms affect atorvastatin lactonization in vitro and in vivo. Clin Pharmacol Ther 87:65-73.

19. Miners JO, Mackenzie PI (1991) Drug glucuronidation in humans. Pharmacol Ther 51:347-69.

20. Miners JO, McKinnon RA, Mackenzie PI (2002) Genetic polymorphisms of UDPglucuronosyltransferases and their functional significance. Toxicology 181-182:453-6.

21. Beutler E, Gelbart T, Demina A (1998) Racial variability in the UDPglucuronosyltransferase 1 (UGT1 A1) promoter: a balanced polymorphism for regulation of bilirubin metabolism? Proc Natl Acad Sci U S A 95:8170-4.

22. Ciotti M, Marrone A, Potter C, Owens IS (1997) Genetic polymorphism in the human UGT1A6 (planar phenol) UDP-glucuronosyltransferase: pharmacological implications. Pharmacogenetics 7:485-95.

23. Kohle C, Mohrle B, Munzel PA, Schwab M, Wernet D, Badary OA, Bock KW (2003) Frequent co-occurrence of the TATA box mutation associated with Gilbert's syndrome (UGT1 A1*28) with other polymorphisms of the UDP-glucuronosyltransferase-1 locus (UGT1 A6*2 and UGT1A7*3) in Caucasians and Egyptians. Biochem Pharmacol 65:1521-7. 
24. The MARIE-GENICA Consortium on Genetic Susceptibility for Menopausal Hormone Therapy Related Breast Cancer Risk (2010) Genetic polymorphisms in phase I and phase II enzymes and breast cancer risk associated with menopausal hormone therapy in postmenopausal women. Breast Cancer Res Treat 119:463-74.

25. Vogel A, Kneip S, Barut A, Ehmer U, Tukey RH, Manns MP, Strassburg CP (2001) Genetic link of hepatocellular carcinoma with polymorphisms of the UDPglucuronosyltransferase UGT1A7 gene. Gastroenterology $121: 1136-44$.

26. Justenhoven C, Pierl CB, Haas S, Fischer HP, Baisch C, Hamann U, Harth V, Pesch B, Bruning T, Vollmert C, Illig T, Dippon J, Ko YD, Brauch H (2008) The CYP1B1_1358_GG genotype is associated with estrogen receptor-negative breast cancer. Breast Cancer Res Treat 111:171-7.

27. Pesch B, Ko Y, Brauch H, Hamann U, Harth V, Rabstein S, Pierl C, Fischer HP, Baisch C, Justenhoven C, Ranft U, Bruning T (2005) Factors modifying the association between hormone-replacement therapy and breast cancer risk. Eur $\mathbf{J}$ Epidemiol 20:699-711.

28. Key T, Appleby P, Barnes I, Reeves G (2002) Endogenous sex hormones and breast cancer in postmenopausal women: reanalysis of nine prospective studies. J Natl Cancer Inst 94:606-16.

Table 1. Frequencies and estimated risks of stressful life events as well as combined UGTIAl and $U G T 1 A 6^{a}$ genotypes in breast cancer cases and controls

\begin{tabular}{lccl}
\hline Variables & $\begin{array}{c}\text { Cases } \\
\mathrm{n}(\%)\end{array}$ & $\begin{array}{c}\text { Controls } \\
\mathrm{n}(\%)\end{array}$ & $\mathrm{OR}^{\mathrm{b}}(95 \% \mathrm{CI})$ \\
\hline $\begin{array}{l}\text { Life event } \\
\text { unmated }\end{array}$ & $50(5.0)$ & $56(5.6)$ & $1.00^{\mathrm{c}}$ \\
married/living with partner & $692(69.2)$ & $665(66.7)$ & $1.18(0.79-1.77)$ \\
divorce/separation/death of husband & $258(25.8)$ & $276(27.7)$ & $1.07(0.70-1.64)$
\end{tabular}




\section{UGT combined}

\section{Life event}

unmated

unmated

married/living with partner

married/living with partner

divorce/separation/death of husband

divorce/separation/death of husband
$303(73.2) \quad 351(80.0) \quad 1.00^{c}$

$111(26.8) \quad 88(20.0) \quad 1.51(1.10-2.09)^{\mathrm{d}}$

UGT combined

$\begin{array}{llll}+ & 17(81.0) & 15(78.9) & 1.00^{\circ}\end{array}$

$\begin{array}{llll}- & 4(19.0) & 4(21.1) & 0.56(0.04-8.72)\end{array}$

$+\quad 216(73.7) \quad 228(77.3) \quad 1.00^{\mathrm{c}}$

$\begin{array}{llll}- & 77(26.3) & 67(22.7) & 1.21(0.83-1.77)\end{array}$

$+\quad 70(70.7) \quad 108(86.4) \quad 1.00^{\mathrm{c}}$

\begin{tabular}{llll}
- & $29(29.3)$ & $17(13.6)$ & $2.61(1.29-5.29)^{\mathrm{e}}$ \\
\hline
\end{tabular}

${ }^{\mathrm{a}} U G T 1 A 1 * 1 / * 28, U G T 1 A 6 \_19 \_\mathrm{T}>\mathrm{G}$ and $U G T 1 A 6 \_541 \_\mathrm{A}>\mathrm{G}$ genotypes were combined according to their known effect on gene expression, women homozygous for the reference alleles $U G T 1 A 1 * 1 / * 1$, UGT1A6_19_TT and UGT_541_AA leading to increased gene expression are designated (+); women homozygous for the variant alle les UGT1A1*28/*28, UGT1A6_19_GG and UGT1A6_541_GG leading to decreased gene expression are designated (-)

${ }^{\mathrm{b}} \mathrm{OR}$ conditional on age in 5-year classes, adjusted for menopausal status, family history of breast cancer, use of oral contraceptives, use of hormone therapy, body mass index, and smoking

${ }^{\mathrm{c}}$ Reference

${ }^{\mathrm{d}} \mathrm{p}=0.012$

${ }^{\mathrm{e}} \mathrm{p}=0.008$

Abbreviations $: \mathrm{CI}=$ confidence interval, $\mathrm{OR}=$ odds ratio, $\mathrm{UGT}=\mathrm{UDP}$ glucuronosyltransferases 